\title{
Reflections on the development and implementation of an enrichment program in early childhood: A metaphorical representation
}

\author{
Susanne Garvis \& Donna Prendergast \\ Griffith University, Gold Coast Campus, Australia
}

\begin{abstract}
The profile of gifted education is being raised in Queensland (Australia) schools in recognition of the potential benefits to students of engaging in such programs. Little is known however about what types of programs are being delivered, especially in the early years. Since many programs are created by individuals, it is important to understand the beliefs and reflections of individual teachers. Beliefs and reflections shape a teacher's practice with young children. This article reports on a case study that explored an Australian early childhood teacher's experience in gifted enrichment programs for children (grade preparatory to year two). The case study documents the teacher's personal practical knowledge of gifted education. Spanning over the development and implementation of an enrichment program, data were collected from field notes, a reflective journal and informal conversations. Metaphor analysis was used as an heuristic tool to explore the lived experience of the teacher as she delivered a program to gifted children in the early years. From this analysis it is possible to identify key themes around professional isolation, professional development and sustainability and flux of self-efficacy beliefs. The study highlights the need to further explore the life cycle of enrichment programs from the lived experience of the teacher to establish a greater understanding of teacher's personal practical knowledge for gifted education in the early years.
\end{abstract}

\section{Introduction}

In Queensland, Australia, gifted education has emerged as a key prerogative directed by the jurisdiction's policy titled Gifted Framework (2004), with guidelines for students, teachers, parents and principals. The Framework provides key identification strategies for selection of these students. It is hoped through explicit policy, the quality of education for students with gifts and talents will improve. In 2008, Education Queensland (the state education department) released an action plan for gifted and talented students to be implemented over the following three years to ensure all teachers and schools are at the maximum level through identified key strategies. This includes the early years of schooling, the focus in this paper. Timelines were set for minimum requirements by schools over this time period.

Within Queensland, limited research has been conducted in the field of gifted education in the early years. Little is known about the types of programs that are being implemented as part of the Gifted Framework implementation for young children. While numerous studies from the United States report on successful programs organised for preschool and preparatory age children, little is known how these programs might operate if translated to an Australian context. As Wellisch (2006) suggests, government inquiries and recommendations for gifted education have been largely ignored by the early childhood field.

Furthermore, little is known about a teacher's knowledge in dealing with gifted programs for young children. According to Connelly and Clandinin (1999), for a teacher, knowledge is entwined with identity. From this conceptualisation we can consider teachers' personal practical knowledge; that is, the experiential, moral, emotional, embodied knowledge teachers hold and express in their classroom practices (Connelly \& Clandinin, 1988). Understanding such teachers' knowledge allows us to develop a narrative understanding about the context in which teachers live and work when engaged with gifted education. Since many teachers may be the sole provider of gifted education, it is important to explore individual beliefs and reflections to provide insight into early years gifted programs.

This paper reports on a case study that explored the teaching cycle of a Queensland early childhood teacher's experience in a gifted enrichment program for children aged five to seven. Using metaphor analysis, it provides insight into the type of program that was 
delivered in Queensland and details about the teacher's knowledge and thinking as the program unfolded. This insight provides us with evidence of the teacher's personal practical knowledge of gifted education, helping to fill the current void in the literature.

Known by the pseudonym 'Mia', the teacher under study shared her experiences to form a case study spanning the duration of the gifted education program for young children. Information was collected from her reflective journal, field notes and a semi-structured interview. The data were combined to create five metaphors as a heuristic tool to describe Mia's practical professional knowledge of gifted education. By doing so, a cycle emerged highlighting the various stages Mia transcended as she used, developed and redeveloped her personal practical knowledge of gifted education.

\section{Rationale}

Identifying gifted children in classrooms can be difficult for teachers. When Gagné's (1993) internationally accepted model of development is applied, it is forecast that $15 \%$ of students in every classroom are gifted. When this is scaled up for the Queensland population, this equates to something like 90,000 students. Given the relatively small numbers of students who are identified as gifted, using Gagné's formula highlights the possibly significant number of students with gifts and talents who remain unidentified within the Queensland system.

Notwithstanding this, some state and private schools are identifying gifted students and run special programs for gifted and talented children. In terms of the effectiveness of these programs, in the United States a survey of teachers, administrators, and gifted and talented program coordinators showed that $98 \%$ felt that special classes were 'academically advantageous' to gifted students, $84 \%$ agreed that motivation ran higher within special classes and $85 \%$ rated the special classes as good for sociol-emotional development of gifted students (Feldhusen \& Sayler, 1990). It is upon such research findings that the initiatives driving the new attention to gifted education in Queensland schools are based.

\section{Characteristics of gifted young children}

The study of gifted education in the early years is not new. Literature provides information about: the early signs of giftedness (Robinson \& Noble, 1991; Sankar-DeLeeuw, 2004); characteristics of gifted education (Ehrlich, 1985; Porter, 1999); early entry (Sankar-
DeLeeuw, 1999); giftedness and play (Harrison \& Tegel, 1999); giftedness in infancy (Harrison, 2000a); and, aspects of cognition (Harrison, 2004).

It is generally accepted that exceptionally gifted children exhibit a higher level of personal maturity in one or more areas than others of the same age or others at similar stages of intellectual and emotional development (Gross, 1993; Hoeksema, 1982). For example, some young children may begin drawing recognisable pictures or use elaborate language at two and a half years of age, or begin reading by three and read fluently by age four (Jackson, 1988, 2003). Other characteristics may include advanced mathematical, musical and artistic abilities (Davis, Rimm, \& Siegle, 2011). Recognising these gifts and providing appropriate programs to young gifted children is important for their development. According to Clark (1992), children's mental powers show rapid growth during the two through five year period, with "[S]peech, mobility, and increasing social involvement all add[ing] to the fast-paced intellectual development" (Clark, 2008, p. 102). It is because of this critical time period that Restak (1986) indicated "the more complex the experience, the richer the environment, the more complex the brain" (p. 91). Thus, young gifted children need to be provided with appropriate gifted programs to help them reach their potential. According to Karnes and Johnson (1991), gifted young children who fail in the early years of school and in family situations may develop negative feelings towards school and become underachievers. However, given the importance of these years, few studies in Australia have documented teacher knowledge about teaching young children in gifted programs.

\section{Early childhood gifted education programs} Since the introduction of the preparatory years in Queensland (children aged 5-6, equivalent to Kindergarten or Reception in other Australian states and territories), parents and guardians have found the position of the Queensland Department of Education and Training inflexible and inadequate (Queensland Association for Gifted and Talented Children [QAGTC], 2008, cited in Gallagher, Smith \& Merrotsy, 2010). Under the current Queensland Department of Education and Training policy, children can only obtain early entry to the preparatory year if they have previously enrolled in an education system in another state or territory or another country (Queensland Department of Education and Training, 2008a). However, early entry into year 1 is allowed by the Department, provided that the child displays appropriate aptitude, ability, social and emotional competence, physical 
development and knowledge and understanding (Queensland Department of Education and Training, 2008b). Early entry to year 1 appears the only option for some parents of young gifted children in Queensland. As such, little is known about how schools cater for young gifted children in Queensland who cannot be accelerated. One approach, as reported in this article, seems to be the rise of enrichment programs for preparatory, year one and year two students.

In a recent Queensland study of parents, teachers and principal views towards provisions for intellectually gifted in the early years, findings suggest that teachers generally expressed reservations about early entry of young gifted children, citing the effect on the social development of the student (Gallagher, Smith, \& Merrotsy, 2010). These authors also found that early entry to Preparatory led to concerns by teachers about early entry to university. Such previous concerns have been reported by Diezmann, Watters and Fox (2001), although there is no research to support these concerns.

Suitable early childhood gifted programs should be based on an understanding of learning (Ceukierkorn et al., 2007; Edwards, 2005). Little is known, however, about the types of gifted education programs that are implemented for young children in preparatory and childcare centres. Given the limited focus on gifted education in the early years, few studies have looked at early childhood gifted education curriculum programs in Queensland or the teacher beliefs behind these programs.

\section{Teachers of young gifted children}

In Australia, only a few teacher education institutions appear to offer future teachers access to gifted education subjects. Teachers of young gifted children, however, require the knowledge and skills necessary to foster productive learning experiences in generalist classrooms. In a Department of Training and Youth Affairs Study (1999), 53\% of Australian teachers indicated they had experience in a specialist area and only $16.5 \%$ indicated that had involved gifted education. Without access and participation in gifted education, teacher knowledge about gifted education may remain low.

There is an extensive body of literature that strongly advocates for specialised teachers in gifted education (Feldhusen, 1997; Maker, 1977; Renzulli, 2001). Clark (1992) states that "few educational decisions have as much influence on the gifted education programs as teacher selection" (p. 474). Arguments to support this advocacy conclude that untrained teachers involved in gifted education tend to overlook large numbers of gifted children (Hughes \& Murawski, 2001). Teachers trained in gifted education also tend to be more supportive of gifted students while untrained teachers tended to be apathetic (Hansen \& Feldhusen, 1994). Teachers had a greater mastery of specific competencies, skills and knowledge that was important to the components of gifted education (Renzulli, 2001).

A review of the literature suggests teachers of gifted education have a perceived number of similar traits and competences (Feldhusen, 1997; Nelson \& Prindle, 1992). In a small study of teachers in New South Wales, Hall (2001) found that practising teachers perceived teachers of gifted youngsters to be academically endowed, committed to ongoing personal and professional growth, experienced, responsible, aware of the dangers of labelling and nurturing of high potential. A teacher of gifted children was to be constantly aware of, and ever ready to meet, the emotional and cognitive needs of the young child. Little is known, however, about how teachers embody and express their knowledge when teaching in gifted education classrooms (personal practical knowledge).

\section{Teacher personal practical knowledge}

Teacher personal practical knowledge informs everything that a teacher does. It is experiential, moral, emotional, embodied knowledge teachers hold and express in their classroom practices (Connelly \& Clandinin, 1988). In regards to gifted education, it is the embodied knowledge teachers hold and express when engaged in gifted education.

Teachers live in a continually shifting social landscape. The shifting landscapes continually shape teacher knowledge and each teacher's identity as they live by stories. Teachers are aware of the larger society plot lines that ripple through schools and universities influencing the contexts and people (Bateson, 2000; Geertz, 1995). As Geertz (1995) noted, “change apparently, is not a parade that can be watched as it passes" (p. 4). In this metaphor statement, Geertz's image of a parade was that of an entire community participating, entering and leaving at different places and times. Sometimes the parade would be spontaneous and other times it would be planned. Geertz (1995) further wrote that "one could contrast then and now, before and after, describe what life used to be like, what it has since become" (p. 1). Change prompts continual reflection of personal practical knowledge. Reflection provides opportunities to document this knowledge on the continual shifting social landscape. 


\section{Method}

This study is shaped by two research questions. These are:

1. What is the personal practical knowledge of the teacher demonstrated over the duration of an enrichment program in the early years of education?

2. Was there a cyclical nature to the personal practical knowledge of the teacher demonstrated?

This study is situated within an interpretivist paradigm that gives priority to understanding the meanings that individuals make of their own experiences (Garrick, 1999). Knowledge is considered to be a subjective "human construction" (Hatch, 2002, p. 13) and is socially constructed (Denzin \& Lincoln, 2000). More specifically, it recognises that realities are "inherently unique because they are constructed by individuals who experience the world from their own vantage point" (Hatch, 2002, p. 15).

In this study a common approach to interpretivist research - metaphor analysis - is employed. Metaphors are devices for making sense of an experience or phenomenon in terms of another (Lakoff \& Johnson, 1980). As a heuristic tool, metaphor analysis has proven useful when investigating perspectives of pre-service teachers (Bullough \& Stokes, 1994; Knowles, 1994; Sumsion, 2002) and early childhood centre directors (Jorde Bloom, 2000). Metaphors are constructions of meaning that address current understanding. According to Lakoff and Johnson (1980), "a large part of self-understanding is the search for appropriate personal metaphors that make sense of our lives" (p. 233). The influence of the metaphor "cumulatively makes bubbles to the surface” (Craig, 2003, p. 191). Metaphors reveal educators' knowledge lived in and over the continuum on the professional knowledge landscape of each schooling context. Moreover, they provide further understanding of the underlying tensions within the complex contexts.

Case study is an ideal methodology when a holistic, in-depth investigation is needed (Feagin, Orum \& Sjoberg, 1991). It is often used to examine individuals' "uniqueness and commonality...their stories...how they function in their ordinary pursuits and milieus" (Stake, 1995, p. 1) in order to gain "greater understanding of the case" (Stake, 1995, p. 15). Moreover, the phenomenon being researched is studied in its natural context, bounded by space and time (Hancock \& Algozzine, 2006). Subsequently, it can help to penetrate situations in "ways that are not always susceptible to numerical analysis" (Cohen, Manion, \& Morrison, 2000, p. 181). This study uses a case study methodology to document the personal practical knowledge of a teacher engaged in an early childhood gifted education program.

The participant (Mia) was recruited via a snowball sampling method. Snowball sampling is a method used to obtain research and knowledge, from extended associations, through previous acquaintances. The researcher had initially sent an email to another presenter of a gifted program (in Queensland) who informed Mia about the project. Mia contacted the researcher as she was interested in the project. Selection of the participant was based on involvement in early childhood gifted education and previous qualifications. In this case, Mia had experience teaching in early childhood education and had recently completed a Master of Education. Mia consented to share her reflections with the researcher after reading and discussing the project.

Mia was asked to take field notes during the duration of the gifted program. She was also involved in informal conversations with the researcher to help prompt her reflection. From these initial discussions, Mia was asked to use these to create a reflective journal to document her written thoughts and ideas. A reflective journal was considered the most reliable instrument for documenting stories of experiences (leading to documentation of personal practical knowledge). The use of stories in teacher research has become increasingly widespread and accepted (see, for example, Alsup, 2006; Ayers, 2001; Connelly \& Clandinin, 1999). Lyons and LaBoskey (2002) define narrative practices as:

intentional, reflective human actions, socially and contextually situated, in which teachers with their students, other colleagues, or researchers, interrogate their teaching practices to construct the meaning and interpretation of some compelling or puzzling aspect of teaching and learning through the production of narratives that lead to understanding, changed practices, and new hypotheses. (p. 21)

Mia was given a book to write her reflections. Her reflections were to include information from conversations with the researcher, field notes and her thoughts. She was asked to date each jotting to provide a sequential ordering of the recorded reflections. At the end of the program Mia gave her reflective journal to the researcher.

From this self-reflection data a research text was created. The text was analysed and 
metaphors constructed to represent the reflections (metaphoric analysis). Mia made notes every week, allowing the teacher to see her own transformation in her beliefs. This type of development is described by Dewey (1938, as cited in Rodgers, 2002) as the desire or duty to actively search for truth and use information gained to make positive change. In the teacher's reflective journal, it was intended to document the experiences presented from the program as they encountered experiences with students, teachers and parents.

\section{The context of the study}

The participant

Mia had been employed as a teacher for seven years before she began working for a Queensland enrichment learning company. She had previously worked in early childhood, primary and secondary education. Mia had enjoyed the early childhood sector the most and had recently completed a Masters of Early Childhood Education.

Initially Mia was involved in the development and program design for early childhood with the enrichment learning company. Part of these duties involved writing programs that complied with Essential Learning Statements (Queensland Studies Authority, 2007) and the Framework for Gifted Education (Education Queensland, 2004). Programs were designed to provide open-ended tasks that all students could engage in within a multi-age classroom (Preparatory to Year 3).

\section{The school}

In 2008 Mia was in charge of delivering the first set of early childhood programs to a private girls' school in Brisbane, Queensland. The children in the school were primarily from Anglo-Australian families from middle and high economic backgrounds. Students were chosen by generalist classroom teachers and the enrichment officer at the school. Generalist teacher selection was based on observations of students. As many of the students were new to the school (starting school for the first time) the generalist teacher was looking for advanced level of functioning based on a checklist provided by the enrichment officer, even though the use of a checklist to identify gifted students is recognised as having limitations. Indeed, Gross (1999) discovered that teacher nomination was the least effective method for identifying giftedness. Furthermore, teacher nominations appear to be susceptible to class and culture bias. Nevertheless, this method of selection was used. Mia continued to prepare the program.

The class consisted of 22 Preparatory, Year 1 and Year 2 students creating an enrichment cluster. An enrichment cluster is a group of students with a common interest (Reis, Westberg, Kulikovich, \& Purcell, 1998). The groups of students meet with an adult who is an expert in the area. Enrichment clusters explore subject matter in considerable depth (Davis, Rimm \& Siegle, 2011). In this case, the interest area was creative writing and storytelling. Over a period of four sessions, each of two hours duration over a term, it was planned that Mia would scaffold the students in their creation of fiction and nonfiction stories. She knew from previous experience that young children were interested in writing about fairies, monsters, mermaids and animals. The synopsis for the workshop read:

Using strategies that stimulate the higher level and imaginative thinking, this workshop encourages gifted and talented students to reach new heights in their imagination and story telling skills by developing complexity and depth. Students will also practise sharing their work with others, as well as giving and receiving feedback.

The program was designed to explore students' personal interests and explore character and plot developments. Mia was also responsible for student reports to parents at the end of the term.

\section{Findings}

This study attempted to make meaning of Mia's lived experience delivering early childhood gifted programs, her interpretations of the experience and her evaluation of enriched learning environments through her practical personal knowledge. It also attempted to see if practical personal knowledge was cyclical.

In the recounts from Mia, five metaphors were identified after analysis. The first of being/ becoming/unbecoming as an early childhood educator showed a journey of continual negotiation and challenge with each new encounter (Cole \& Knowles, 2000). The metaphor selected was 'planning for a surprise party'. The next four were dialectical and showed the unfolding of travelling the diverse professional landscape characterised by different spaces, places, people and events (Clandinin \& Connelly, 1995). In a journey, one shapes and is shaped by the landscaped travelled (Clandinin \& Connelly, 1995). The four metaphors included 'trying to find the light in no-man's land', 'watching like a hawk', 'letting the wheels rotate' and 'having to pack a suitcase'. The metaphors combined to show a cyclical nature in teacher personal practical knowledge for gifted education in the early years. 
The five metaphors that emerged from analysis in Mia's reflective journal will now be presented, and where appropriate, direct quotes from the journal will be included in italicised text to facilitate the teacher's voice being presented in the paper. The five metaphors show the cyclical nature of Mia's personal practical knowledge over the duration of the enrichment program.

\section{Planning for a surprise party}

Before Mia even began teaching at the school, she had commenced planning the four workshops she was to deliver to the early childhood classroom. Having read literature on program planning in gifted education, Mia wanted to ensure that underlying the program were key values of challenge, choice, interest, enjoyment and personal meaning (Gentry \& Ferriss, 1999). The key values would combine to help motivate students, promote excellence and help students develop habits of learning in a community of practice. Mia had been in previous schools where gifted programs were ad hoc. She did not consider these programs appropriate for students. While they may have had content that was academically challenging, they did not ensure that students would find the content intellectually stimulating. Programs must have a high and optimal level of challenge combined with intellectual stimulation to produce students in a state of 'flow' (Siegle \& McCoach, 1999). Mia initially found it difficult to plan a program for students she had never met. She knew nothing about the students' ability, interests or ages. Glimpses of panic appeared in her writing.

\section{It felt a little strange having to write a} program for students I knew nothing about. I didn't know what they were capable of. I didn't even know what their interests were. I had to start with a completely blank slate. This is really, really difficult.

Mia used an analogy of planning for a surprise party in her reflective journal to show her initial personal practical knowledge as a teacher. She drew on a past experience to help inform her current experience and inform her teaching. This experience became her overarching metaphor for the initial planning.

Planning for the unknown is like planning for a surprise birthday party. You never know what is going to happen until you get there. You have all the invited guests ready to go, you have planned all the food and decorations, and then you just have to wait for the birthday person to show up. It is only when that person enters the room that everything starts to play out. You have no idea how it is going to turn out. You just have to sit back and anticipate an outcome.
You cross your fingers and hope that the surprise party will work.
I decided to follow several guides and assumptions that underlie curriculum theory in gifted education (Maker \& Nielson, 1996; Renzulli, Gubbins, McMillen, Ecert \& Little, 2009; Tomlinson, 2009; Van Tassel-Baska, 2000, 2003; Van Tassel-Baska \& Stambaugh, 2008). This meant all students should experience a high-quality engaging and challenging curriculum that meets present and future academic needs. The curriculum needs to cut across domains including cognitive, affects and social areas of development.

Even though Mia had planned a curriculum for the students, she continued to be nervous. She knew how to write the program but wanted to know about the students. She realised that student interest was important in the learning process. She realised in gifted education how important it was to ensure that students were engaged in the task, otherwise what was the point of the program.

\section{I just feel really bad I don't know anything about the students. If you know what students enjoy you can change the topics accordingly. I will have to make so many adjustments on the first day. I will need to also have my strong observation skills ready to go.}

2. Trying to find the light in no-man's land When Mia entered the all-girls private school, she did not know what to expect. She was initially excited but also scared of the expectations from the school and parents. Mia had gone to an all-girls school but never taught in an all-girls school. She again relied on her past experiences as a student to help navigate the new landscape she was encountering.

I was so scared on my first day. I was in this strange place where I wasn't really a teacher at the school, I wasn't a parent and I wasn't a member of the community. I was an outsider who would come in four times. It was a really strange feeling not to be a part of a school community. When I was in a permanent position, I remember the feeling of belonging, of people knowing your name. This was a more corporate, business feeling. I felt like I was in no-man's land. It was only me in this place, with no-one to turn to if I needed help. I was being paid to be an expert in enrichment learning. The more I thought about no-man's land, the more scared I became. 
In a previous position as an enrichment officer in a school, Mia had felt professional isolation. In her previous position she did not have other staff members to draw upon for support. She was considered the expert in charge of gifted education. Mia linked this prior experience to her current experience of walking into the school. Again she was to adopt the expert identity. Mia's sense of being lost could have resulted from a decline in teacher self-efficacy caused by a new experience. Teacher selfefficacy is defined as "beliefs in one's capabilities to organise and execute the courses of action to produce given attainments" (Bandura, 1997, p. 3). Even though Mia had been teaching for a while, she had now encountered a new context. Teacher self-efficacy theory suggests that when teachers change context, such as a school location or a year level, teacher self-efficacy beliefs enter a state of flux (Tschannen-Moran \& Woolfolk Hoy, 2001). Once experience has been gained in the new context, teacher self-efficacy beliefs begin to stabilise.

The metaphor of no man's land in Mia's diary was also instrumental in alerting Mia to finding positive experiences in her reflections to help resolve the initial tensions she had felt in her personal practical knowledge. Absorbed initially by feelings of not belonging to the school community, Mia soon found what she called 'light' by seeing the respect the school and children had for her. Even though she realised that she would again be in isolation in the school and would not be able to collaborate with the generalist classroom teacher, she began to realise that she would just have to get on with the job. The only person she could call upon herself and that she needed to try and incorporate exemplary pedagogy practice.

The children were all really excited to see me as were the teachers in the school. I began to feel relaxed. The children were really interested to learn and you could see their little faces light up as I spoke about what we were going to do. I knew that lookthe children still had a thirst for learning. I've gotta keep that going. I just know that look and once you see it you need to keep supporting the children in their quest. Each child will have a slightly different interest in the topic but you just have to be able to cater for all the children and be able to spark all of their interests.

Motivated by the possibilities available to her in this new space for her enrichment program, Mia's new sense of light escalated into a "passionate creed" (LaBoskey, 1994) for teaching creativity in the early years. Her creed was to allow the students to engage in creative thinking throughout the writing and storytelling workshop. Mia began to cater for the students by allowing them to develop their own story plot. Mia allowed students to work by themselves or in groups before a sharing time at the end of the session. She would move around the different groups providing suggestions and prompting the students to think in different ways.

After the session Mia went home and wrote about the importance of a school having a shared vision for gifted education that was the responsibility of the entire school. She wrote that even in this current school a shared understanding about enhancing the learning of gifted student was not evident. She began to wonder if this could ever be achieved in a school or if individual members within a school, such as enrichment officers, are always in 'no man's land' with occasional glimpses of light.

\section{Watching like a hawk}

During the first two sessions, Mia wrote a metaphor of becoming a hawk. She would try to watch everything occurring in her class and make mental notes to herself about the children. From this habit came continual readjustments of the curriculum. Mia thought this was a vital strategy for helping with her continual renewal of her personal practical knowledge about the class. It would also help keep the children on task.
I had to really think about what I was observing. I then had twenty seconds to make an adjustment to the activity for some children. I enjoy thinking on the spot but I had to use all the knowledge to make an immediate decision.

One of the immediate changes Mia reflected on was the introduction of playmaking to the story telling.
I started a small group off with the task of turning their story into a running script. After an initial run through, the group stopped and began to have a discussion about the animals and the monster in the story. What happened? How could they improve it to make the story even scarier? The five and six year olds decided to break down the story and rehearse scene by scene.

Playmaking is the activity of acting out a story without a script. Children must be conscious of their movement, gestures, and be able to organise the plot as it evolves. According to Carelli (1981), gifted children involved in playmaking will select a theme, assign responsibilities, plan and implement activities 
and be able to evaluate both the process and the final product.

Mia began to notice creative characteristics emerge in the children's story telling. She wondered if the generalist classroom teachers had also seen these characteristics.

We had a group session where we shared our ideas. The students sat in a big circle on the carpet. They were all excited to share their ideas. As I watched and listened, I started to identify early characteristics of creativity. I saw things like risk-taking, sharing and trusting occurring in the group and self-discipline by five year olds to stay focused on the task of storytelling. I wish I could discuss this with their generalist teacher. Do they see this too or just me?

These characteristics could be summarised as the beginnings of the four characteristics of highly creative people (Piirto, 2005), including naiveté, self-discipline, risk-taking and group trust. Mia could identify them (having learnt them in her Master's degree) but wondered if others in the school also knew about these characteristics. Mia had initial ideas of running a professional development workshop for teachers at the school but decided against it. As a visitor to the school Mia did not think it would be appropriate. She had also tried professional development opportunities with staff at her previous position as an enrichment officer.

I remember I again observed (like a hawk) what was going on in my last school and wanted to help inform the level of knowledge amongst the teachers. I thought we could all work together for gifted education. I organised an afternoon for staff and parents. Thirty parents showed. No staff members came after school. It felt a lost cause. If we observe and notice problems, surely we should all try and fix it together.

\section{Letting the wheels rotate}

Over the next few sessions, Mia referred to the metaphor of letting the wheels rotate. After initially monitoring and observing the children intensely, Mia began to relax into the natural flows of the workshops. In her writings her own perceived capability began to stabilise. She realised that she would not be able to communicate with other staff members in the school. The children would come to the workshops and leave. Mia began to realise that while she was able to help enhance the thinking and writing of the children, it was short term. She began to question why schools did not have dedicated programs with classes of gifted students. Why were pull-out programs (conducted in isolation) popular in many schools with little long term development beyond a finite number of workshops.

Mia's personal practical knowledge became more reflective. She began to wonder why gifted children were not catered for in their generalist classroom. Mia considered this the best place for enhanced learning as the child was not removed from the classroom. She thought back to her own Bachelor Degree training and realised that gifted education was not covered in any lecture or tutorial. Mia questioned if a pull-out program was the best solution if no-one else had qualifications in gifted education. Her thinking appeared to rotate around like a wheel.

Mia began to reflect on the space she had established with the young children. Mia felt that the room had created its own unique creative atmosphere that was continually on the move. The room appeared to feel safe for all learners where risks in creative thinking could be taken. Rogers (1962) calls 'psychological safety' a prerequisite for creative thinking.

The space was safe for everyone and it just kept rolling along. I wondered though, did the children go back to this type of space in other parts of school? If not, doesn't this create confusion for the children? Doesn't it teach them that you can take risks but only in certain classes at certain times in only some subject areas?

Mia realised that she was responsible for maintaining the environment for all students to try and enhance their risk taking behaviour during this time. She was responsible for creative teaching and learning. Part of this commitment meant maintaining high teacher enthusiasm and encouraging and not being afraid of wandering off the curriculum plan to something different (Torrance, 1995).
I soon realised I just had to follow the children and always show enthusiasm. I started to have a lot of fun with the teaching. I don't even think I would call it teaching. It is facilitation of ideas. We began to explore a variety of areas. I guess if you were teaching a traditional classroom curriculum you would be not allowed to wonder over the place with the children's ideas. I mean all the content gets covered but in a way that the children understand, not the prescribed curriculum with a set learning style.

Mia's reflections emphasise Reis et al's (1998) four principles of enrichment teaching and 
learning. These included: (1) each student is different; (2) learning is more effective when students enjoy what they do; (3) learning is more meaningful when students learn content and process while solving a real problem; and (4) a major goal is promoting knowledge and thinking skills, allowing students to construct their own meaning. Mia suggested she had developed this thinking from the knowledge gained from her Masters course and also trial and error in the classroom.

Mia wrote about the creative techniques she wanted to use with the students to engage in creative writing and storytelling. Mia wanted the children to become descriptive story tellers of fiction and non-fiction (part of her passionate creed). She realised she had to keep answers open in hypothetical questions so the children could explore a range of topics.

\section{I wanted questions that would promote} Bloom's (1974) classic higher order thinking skills of analysis, synthesis and evaluation. Many of our stems for stories would start a statement of "what would happen if...?" One day I started with "what would happen if the sun didn't get out of bed?" The five, six and seven year olds were really into this hypothetical. The ideas they came up with were extraordinary. At times I thought I was in an experienced university short story class. The expression and fluency in writing showed originality.

Mia also wrote of using visualisation and imagination in the workshops to encourage creative thinking. She used these pedagogical strategies from her personal practical teacher knowledge to help the children. She found it a useful strategy in the second workshop and decided to use it for others.

Visualisation and imagination are central creative abilities (Piirto, 2004). One lesson I decided to take the group outside. We all found our own individual space, shut our eyes and relaxed. I asked the students to hold out both arms and become the wind. Swing and sway as the wind dances and tells a story. Next, the students began to write down the story the wind had told them. I was astonished at their complex ideas. These children were so young. The students must get really bored with concrete learning in schools where creative thinking is not encouraged.

5. Having to pack the suitcase The final stage in Mia's reflective journal was summarised in the metaphor of packing a suitcase. Mia knew that the program must soon come to an end, associated with all the administration duties.

It is like when you need to pack your suitcase. You create a list of all the things you need to take and check them off as you place them in the suitcase. At the end of the program, I also have a big list of administration duties to get through and check off. For example, I have to do all the report cards for the parents and school. I need to ask the students to fill in an evaluation. I need to write a report for the school.

Evaluation was an important part of the final program. This included providing parents with a report card about their students in various criteria and student self-evaluations. The report card was largely based on Mia's observation of the child's progress in the workshops. Students were assessed under the categories of: (1) understanding of the subject matter; (2) problem solving and creativity; (3) attitude to studies; and (4) participation. A four-point Likert scale was used, which ranged from 1 as 'unsatisfactory' to 4 as 'excellent'. These categories were already structured into the report structure given by the enrichment agency. At the end of the report Mia was also asked to write comments. Mia enjoyed writing the comments the most on the report. She did not enjoy having to rank the students but realised that parents were familiar with a ranking system from school report cards.

All students were given a self-evaluation sheet. Self-evaluations provided students with a clear measure of accomplishment relative to the student's own goals and objectives. Students were also asked to rate the teaching and skills of the presenter Mia, who would be shown the feedback two months after it had been compiled.

I really liked this concept. It would help me improve for next time. When you are teaching in a generalist classroom you don't have time for the feedback loop. How can you improve unless the children are telling you. Their feedback allows me to think about things in different ways.

After all the administration tasks had finished, Mia began to question the future of the students. She was worried if the school would provide other gifted education opportunities. Her reflective practice began to emerge in her practical personal knowledge.

What is supposed to happen to their learning now? Will they do another 
workshop with another presenter next semester? Will the school system nurture their creativity further? Will they be allowed to use imagination in their classroom?

Mia realised that the students required further help in their development. Mia was worried that this program, like others, would be disconnected from the generalist teacher classroom and be considered a 'one-off' program for academically able students as a break from their traditional classroom. Mia highlighted the problem in her journal:

\section{I asked one student what the teacher thought about them missing maths. The student said she was told to catch up on the pages of the maths book during lunch time and to see the teacher if there were any problems. The poor student had to do more work, not different work!}

\section{Discussion}

While metaphors highlight certain aspects of personal experience, they also leave other areas in shadow (Lakoff \& Johnson 1980). In this study we learn little about the actual step by step approach of Mia's teaching. We also learn little of how Mia communicated with other members in the immediate school community. Nevertheless, Lakoff and Johnson (1980) suggest metaphors appear to be a useful tool for "trying to comprehend partially what cannot be comprehended totally" (p. 193). From this study, we were able to gain insight into Mia's personal practical experience of teaching an early years enrichment program for prep year to year two students in Queensland, Australia. As such, metaphors enhanced our efforts and provided a frame to understand Mia's lived experience.

Mia's metaphors highlight alternative forms of representing her personal practical teacher knowledge. From the metaphors, key themes emerge about professional isolation, the importance of professional development, collaboration in schools and the sustainability of gifted education. The paper will now turn to the two research questions.

1. What is the personal practical knowledge of the teacher demonstrated over the duration of an enrichment program in the early years of education?

It is apparent that Mia's metaphors focus on the personal and awareness of school cultures. The metaphors show some awareness of school communities, student learning, teachers' work and creative teaching and learning. This suggests that Mia is an experienced teacher, moving beyond the personal. Her awareness of these dynamics offered guidance about how she might foster learning in the creative writing and storytelling enrichment program.

We also see in her personal practical knowledge the potential barriers she finds with the young gifted education program in the school. Firstly, Mia feels professional isolation in this school. She also notes that she felt professional isolation as the enrichment officer at her last school. Without suitable mentors and colleagues in similar roles, Mia cannot increase her knowledge of gifted education through conversations or learn from modelling and observation. Rather Mia is reliant on what she can read in academic journals and through trial-and-error of teaching methods.

Mia's personal practical knowledge about the delivery of gifted education was informed by her Masters study. Her knowledge of the academic literature guided her with to make informed choices in her decision making. This confirms previous research about the importance of having specialist trained teachers for gifted education (Renzulli, 2001). Mia admitted that she did not engage with gifted education in her Bachelor Degree. Mia's statements confirm Hall's (2001) postulation that few, if any mastery subjects are offered in gifted education for preservice teachers. This raises questions about teacher education in Queensland, Australia. If pre-service teachers are not given adequate time in teacher education to learn about gifted education, it is unlikely they will know how to cater for gifted students in their classroom. With limited prior experience from teacher education to draw upon, some teachers may prefer to outsource the teaching of gifted education to others in the school. This may also explain Mia's past experience with trying to organise professional development in a school where no staff members attended. Given that all teachers in Queensland are expected to have a working knowledge of gifted education (see Gifted Education Framework, 2004) problems arise of where gifted education knowledge is taught or accessed.

2. Was there a cyclical nature to the personal practical knowledge of the teacher demonstrated?

When taken as a sequence, the metaphor cycle of personal practical knowledge reveals a transition in and out of an early childhood enrichment program showing teacher reflective practice. The sequence provides an understanding of how the teacher makes 
meaning of her own professional experience in decision making given the short space of time for the program. It also allows insights into the feelings and thoughts of the gifted education. From this, it is possible to develop a greater understanding of Mia's teacher knowledge towards teaching early childhood enrichment programs.

Collectively, Mia's metaphors point to the complexities of the challenges encountered with teaching early childhood enrichment programs and the responsibilities needed to prepare suitable teaching environments. Even as an experienced teacher, Mia still had an initial state of flux with her sense of self-efficacy before her beliefs settled with the new context. From this perspective, teacher self-efficacy can be expected to influence the success of gifted education programs. As a teacher becomes more familiar with the students, content and space their beliefs about their own capabilities increases, leading to an increased sense of selfefficacy beliefs in students. In Mia's case, by the time she had regained her sense of teacher selfefficacy, the program had ended, pointing to the need for longer duration programs.

\section{Future Research}

Despite the power of the Mia's five metaphors, it is clearly not possible to generalise from one early childhood teacher experience to another. Nor it is advisable to offer prescriptive suggestions based on only Mia's lived experience. The strength of this study however, is that it "invites the reader into conversation and to compare their own experience and understanding with that described in the case study" (Bullough et al., 1991, p. 12). Through such conversations we can develop collective understandings about gifted education. In what follows, we outline what we think might be potentially useful for future conversation regarding the implementation of early childhood enrichment programs by teachers.

First, there seems to be a cycle to teachers commencing early childhood enrichment programs. Even experienced teachers experience anxiety in relation to learning and teaching in new contexts. As this study has shown, while Mia was an experienced teacher, she still went through a cycle of personal feeling in delivering the enrichment program. It might be appropriate then, for future investigation of teaching enrichment programs to focus on possible teaching cycles. Since teacher beliefs influence teacher capability, it is an important contributor to delivery of successful and productive gifted education programs.
Secondly, teacher beliefs may also warrant investigation into perceived student capability. Mia wrote of excitement at what students were capable of in her creative writing and storytelling class. Rather than having a fixed curriculum, Mia operated a classroom that was always open to change. Mia allowed the students to construct their own meaning. In many classrooms, early childhood teachers may already have pre-conceived ideas about what young children are capable of. This view may be at difference to what the gifted young child may be capable of.

Change in perceptions in gifted education may also be brought about by further professional learning. All teachers should have a working understanding of gifted education, especially for young children. Mia had learnt skills for enhancing creative learning from her Master's degree. Mia was then able to apply these to her own teaching. How important is professional learning to improve gifted education in Queensland, Australia? How can we provide positive professional learning that is capable of changing negative teacher beliefs? What additional aspects of early childhood education require attention to help change perceptions of young gifted children? These questions point to the need for collaborative efforts by teachers, teacher educators, school administrators and policy makers if we are to address these concerns.

This study also shows a point in time example of what a Queensland school is doing to cater for young gifted students. In Mia's reflections we see questions about the sustainability of the programs for students and the difference that may result between the enrichment classroom and the generalist teacher classroom. This example raises questions about the focus of gifted education within the school and the role of the generalist teacher. Future research could examine principal and generalist teacher responsibilities towards gifted education in Queensland, Australia.

Finally, this study also highlights the importance of metaphors in studying teacher experience. Metaphors created a frame of reference through which Mia could reflect on her own experience as an early childhood educator. As the workshops unfolded, Mia was able to provide meaningful representation of her evolving experiences. Her metaphor of 'watching like a hawk', for example, reflected her observational techniques in the first two workshops to continuously observe, interpret and adjust tasks for students. The sharing of metaphors in communities of practice may be particularly important. Collegial discussions about one's experience and 
expectations of early childhood teachers towards gifted education may generate insights into one's own and others' perspectives and actions. One outcome may be to assist other early childhood teachers to recognise the ways in which their metaphors shape their beliefs towards teaching young gifted students.

\section{Conclusion}

This case study documented a teacher's personal practical knowledge of gifted education in Queensland Australia. Using metaphor analysis the study provided reflective insight into professional isolation, professional development and learning and sustainability of enrichment programs in schools for young children. The study also provided insight into the teaching cycle that spanned the duration of the enrichment program for young children. The cycle revealed fluxes in teacher self-efficacy. Since personal practical knowledge informs a teacher's practice in the early years, the study highlights the need to further explore the life cycle of enrichment programs from the lived experience of the early childhood teacher to establish teachers' personal practical knowledge for gifted education.

\section{References}

Alsup, J. (2006). Teacher identity discourses: Negotiating personal and professional space. Mahwah, NJ: Lawrence Erlbaum Associates.

Ayers, W. C. (2001). To teach: The journey of a teacher. New York: Teachers College Press.

Bateson, M. C. (2000). Full circles, overlapping lives. New York: Ballantine Books.

Bandura, A. (1997). Self-efficacy: The exercise of control. New York: W.H. Freeman.

Bullough, R. V., Knowles, J. G. \& Crow, N. A. (1991). Emerging as a teacher. London: Routledge.

Bullough, R.V., \& Stokes, D.K. (1994). Analyzing personal teaching metaphors in preservice teacher education as a means of encouraging professional development. American Educational Research Journal, 31(1), 197-224.

Carelli, A. O. (1981). Creative dramatics for the gifted: A multi-disciplinary approach. Roeper Review, 5(2), 29-31.

Clandinin, D. J., \& Connelly, F. M. (Eds.). (1995). Teachers' professional knowledge landscapes. New York: Teacher College Press.

Clark, B. (1992). Growing up gifted (4 ${ }^{\text {th }}$ Ed.), New York: Macmillan.

Clark, B. (2008). Growing up gifted: developing the potential of children at home and at school. New Jersey: Pearson.

Cline, S. (1998). The cline cube: integrating models of gifted education. In: J. F. Smutny (Ed.), The young gifted child: Potential and promise, an anthology, (pp.420-431), New York: Hampton Press.
Cole, A. L., \& Knowles, J. G. (2000). Researching teaching: exploring teacher development through reflexive inquiry. Needham Heights, MA: Allyn \& Bacon.

Connelly, F. M. \& Clandinin, D. J. (1999). Shaping a professional identity. New York: Teachers College Press.

Craig, C. J. (2003). School portfolio development: A teacher knowledge approach, Journal of Teacher Education, 54(2), 122-135.

Cukierkorn, J. R. Karnes, F. A., Manning, S. J., Houston, H., \& Besnoy, K. (2007). Serving the preschool gifted child: Programming and resources. Roeper Review 29(4), 271-276.

Davis, G. A., Rimm, S. B., \& Siegle, D. (2011). Education of the gifted and talented $\left(6^{\text {th }}\right.$ ed). Upper Saddle River, NJ: Pearson.

Denzin, N. K., \& Lincoln, Y. S. (Eds.). (2000). Handbook of qualitative research $\left(2^{\text {nd }}\right.$ ed). Thousand Oaks, CA: SAGE.

Department of Education, Training and Youth Affairs. (1999). Teachers in Australian schools: A report from the 1999 national survey. Canberra: Australian Government.

Diezmann, C. M., Watters, J. J., \& Fox, K. (2001). Early entry to school in Australia: Rhetoric, research and reality. The Australasian Journal of Gifted Education, 10(2), 5-18.

Education Queensland. (2004). Framework for gifted education. Brisbane: Queensland Government.

Edwards, S. (2005). Children's learning and developmental potential: examining the theoretical informants of early childhood curricula from the educator's perspective. Early Years 25 (2005), 67-80.

Ehrlich, V. Z. (1985). Gifted children: A guide for parents and teachers. New York: Trillium Press.

Feagin, J., Orum, A., \& Sjoberg, G. (Eds.). (1991). A case for case study. Chapel Hill, NC: University of North Carolina Press.

Feldhusen, J. F. (1997). Education teachers for work with talented youth. In N. Colangelo \& G. Davis. Handbook of gifted education. $2^{\text {nd }} E d$. Boston: Allyn \& Bacon.

Feldhusen J. F., \& Sayler, M. F. (1990). Special classes for academically gifted youth. Roeper Review, 12, 244-249.

Gagné, F. (1993). Constructs and models pertaining to exceptional human abilities. In K. A. Heller, F. J. Monks \& A. H. Passow (Eds.), International handbook of research and development of giftedness and talent (pp. 63-85). Oxford: Pergamon Press.

Gallagher, S., Smith, S., Merrotsy, P. (2010). Early entry: When should a child start school? Australasian Journal of Gifted Education, 19(1), 16-23.

Garrick, J. (1999). Doubting the philosophical assumptions of interpretive research. Qualitative Studies in Education, 12(2), 147-156.

Gentry, M. L., \& Ferriss, S. (1999). A model of collaboration to develop science talent among rural middle school students. Roeper Review, 21, 316-320.

Geertz, C. (1995). After the fact: Two countries, four decades, one anthropologist. Cambridge: Harvard University Press.

Gross, M. U. M. (1993). Exceptionally gifted children. New York: Routledge. 
Gross, M. U. M. (1999). Relationships between selfesteem and motivational orientation among gifted students in full-time programs. In N. Colangelo and S.G. Assoline (Eds.), Talent Development III. Scottsdale: Gifted Psychology Press.

Hall, J. (2001). Teacher thinking: perceptions of the teacher of the gifted. Australasian Journal of Gifted Education, 10(2), 19-28.

Hansen, J. B. \& Feldhusen, J. F. (1994). Comparison of trained and untrained teachers of gifted students. Gifted Child Quarterly, 38(3), 115-121.

Harrison, C. (2000a). Gifted infants: The realities of the first weeks and months. Gifted, 115, 27-29.

Harrison, C. (2004). Giftedness in early childhood: The search for complexity and connection, Roeper Review, 26(2), 78-84.

Harrison, C., \& Tegel, K. (1999). Play and the gifted child. In E. Dau (Ed.), Child's play: Revisiting play in early childhood settings (pp. 97-110). Sydney: Maclennan \& Petty.

Hatch, J. A. (2002). Doing qualitative research in educational settings. Albany: State University of New York.

Hoeksema, F. M. (1982). Identifying intellectual advancement in preschools. (ERIC Document Reproduction Service No. ED 235 923).

Hughes, C. E., \& Murawski, W. A. (2001). Lessons from another field: Applying coteaching strategies to gifted education. Gifted Child Quarterly, 45(3), 195-204.

Jackson, N. E. (1988). Precocious reading ability: What does it mean? Gifted Child Quarterly, 32, 196-199.

Jackson, N. E. (2003). Young gifted children. In N. Colangelo \& G.A. Davis (Eds.), Handbook of gifted education ( ${ }^{\text {rd }}$ ed.; pp. 470-482). Boston, MA: Allyn \& Bacon.

Jorde Bloom, P. (2000). Images from the field: How directors view their organizations, their roles and their jobs. In M.L. Culkin (Ed.), Managing quality in young children's programs: The leader's role (pp.59-77). New York: Teachers College Press.

Karnes, M. B., \& Johnson, L. J. (1991). The preschool/primary gifted children. Journal for the Education of the Gifted, 14(3), 267-283.

Knowles, J. G. (1994). Metaphors as windows on personal history. A beginning teacher's experience. Teacher Education Quarterly, 21(1), 37-66.

LaBoskey, V. L. (1994). Development of reflective practice: A study of preservice teachers. New York: Teachers College Press.

Lakoff, G., \& Johnson, M. (1980). Metaphors we live by. Chicago: University of Chicago Press.

Little, C. A. (2009). The integrated curriculum model. In B. MacFarlane \& T. Stambauch (Eds.), Leading change in gifted education: The Festschrift of Dr Joyce Van Tassel-Baska (pp.271-284). Waco, TX: Prufrock Press.

Lyons, N. \& LaBoskey, V. (2002). Narrative inquiry in practice: Advancing the knowledge of teaching. New York: Teachers College Press.

Maker, C. J. (1977). Providing programs for the gifted handicapped. Reston: Council for Exceptional Children.

Maker, C. J., \& Nielson, A. B. (1996). Curriculum development and teaching strategies for gifted learners. Austin, TX: Pro-Ed.

Nelson, K. C. \& Prindle, N. (1992). Gifted teacher competencies: Ratings by rural principals and teachers compared. Journal for the Education of the Gifted, 15 (4), 357-369.

Piirto, J. (2004). Understanding creativity. Scottsdale, AZ: Great Potential Press.

Piirto, J. (2005). The creative process in poets. In J. C. Kaufman \& J. Baer (Eds.), Creativity across domains. London: Psychology Press.

Porter, L. (1999). Gifted young children. St Leonards, NSW: Allen and Unwin.

Queensland Department of Education and Training. (2008a). School admission and profession age 1875:2008. Retrieved 15 November 2010 from http://education.qld.gov.au/library/edhistory/top ics/age.html

Queensland Department of Education and Training. (2008b). Early entry to year 1: Parent Information. Retrieved 15 November 2010 from http://education.qld.gov.au/strategic/eppr/stude nts/smspr007/pieey1.doc

Queensland Studies Authority. (2007) Essential Learning Statements. Retrieved June 7, 2010 from http://www.qsa.qld.edu.au/574.html

Reis, S. M., Gentry, M., \& Maxfield, L. R. (1998). The application of enrichment clusters to teachers' classroom practices. Journal for Education of the Gifted, 21, 310-334.

Reis, S. M., Westberrg, K., Kulikovich, J., Caillard, F., Hebert, T., Purcell, J., Rogers, J., \& Smist, J. (1992, April). Modifying regular classroom instruction with curriculum compacting. In J. S. Renzulli (Chair), Regular classroom practices with gifted students: Findings from the National Research Center on the Gifted and Talented. Symposium conducted at the meeting of the American Educational Research Association, San Francisco, CA.

Renzulli, J. S. (1994). Schools for talent development: A practical plan for total school improvement. Mansfield Center, CT: Creative Learning Press.

Renzulli, J. S. (2001). Expanding the conception of giftedness to include co-cognitive traits and promote social capital. Storrs, CT: The National Research Centre on the Gifted and Talented.

Renzulli, J. S., \& Gubbins, E. J., McMillen, K. S., Ecerkt R, D., \& Little, C. A. (Eds.). (2009). Systems and models for developing programs for the gifted and talented $\left(2^{\text {nd }}\right.$ ed. $)$. Mansfield Center, CT: Creative Learning Press.

Restak, R. (1986). The infant mind. Garden City, NY: Double Day.

Robinson, N., \& Noble, K. (1991). Social-emotional development and adjustment of gifted children. In M.C. Wang, M.C. Reynolds, \& H. J. Walberg (Eds.), Handbook of special education: Research and practice: Vol. 4, Emerging programs (pp.57-76). New York: Pergamon Press.

Rogers, C. R. (1962). Toward a theory of creativity. In S. J. Parnes \& H. F. Harding (Eds.), A source book for creative thinking. New York: Scribners.

Rogers, K. B. (2002). Reforming gifted education: How parents and teachers can match the program to the child. Scottsdale, AZ: Great Potential Press.

Sankar-DeLeeuw, N. (1999). Gifted preschooler: Parent and teacher views on identification early admission and programming. Roeper Review, 21(3), 174-179.

Sankar-DeLeeuw, N. (2004). Case studies of gifted kindergarten children: Profiles of promise. Roeper Review, 26(4), 192-207. 
Siegle, D., \& McCoach, D. B. (1999, November). Academic challenge: Are we barking up the wrong tree? Presentation at the $46^{\text {th }}$ Annual Convention of the National Association for Gifted Children, Albuquerque, NM.

Stake, R. E. (1995). The art of case research. Thousand Oaks, CA: Sage Publications.

Sumison, J. (2002). Becoming, being and unbecoming an early childhood educator: A phenomenological case study of teacher attrition. Teaching and Teacher Education, 18, 869-885.

Tomlinson, C. A. (2009). The parallel curriculum model: A design to develop potential \& challenge high-ability learners. In J. S. Renzulli, E. J. Gubbins, K. S. McMillen, R. D. Eckert, \& C. A, Little (Eds.), Systems and models for developing programs for the gifted and talented $\left(2^{\text {nd }}\right.$ ed.; $\mathrm{pp}$. 571-598). Mansfield Center, CT: Creative Learning Press.

Torrance, E. P. (1995). Why fly?: A philosophy of creativity. Norwood, NJ: Ablex.

Tschannen-Moran \& Woolfolk Hoy, A. W. (2001). Teacher efficacy: Capturing an elusive construct. Teaching and Teacher Education, 17(7), 783-805.

VanTassel-Baska, J. (2000). Theory and research on curriculum development for the gifted. In K. A. Heller, F. J. Monks, R. J. Sternberg, \& R. F. Subotnik (Eds.), International handbook on giftedness and talent ( $2^{\text {nd }}$ ed.; pp. 345-365). London: Pergamon Press.

VanTassel-Baska, J. (2003). Content-based curriculum for low income and minority gifted learners (RM03180). Storrs, CT: The National Research Center on the Gifted and Talented.

VanTassel-Baska, J., \& Stambaugh, T. (2008). What works: 20 years of curriculum development and research for advanced learners. Waco, TX: Prufrock Press.

Wellisch, M. (2006). Where are the gifted under fives? Inclusion and support programs for gifted children. Every Child, 12(3), 30-31.

\section{Contact details}

Dr Susanne Garvis

School of Education and Professional Studies, Griffith University Gold Coast Campus,

QLD, 4222

Email: s.garvis@griffith.edu.au

Ph: (07) 55529789

Professor Donna Pendergast

School of Education and Professional Studies, Griffith University Gold Coast Campus

QLD, 4222

Email: d.pendergast@griffith.edu.au

\section{Biographical details}

\section{Susanne Garvis}

Dr Garvis worked in the areas of early childhood education and arts education before joining Griffith University. She currently teaches in the early childhood program. Susanne's research interests include early childhood education, gifted education and the use of narrative inquiry.

\section{Donna Prendergast}

Professor Donna Pendergast has an international profile in the field of middle schooling; and in family and consumer science. Recently, she has extended this focus to include the early years. She has conducted a number of national research projects of significance. 